\title{
Implementasi Sensor Gas MQ-136 Dan MQ-137 Untuk Mendeteksi Kesegaran Daging Sapi Menggunakan Metode Neural Network
}

\author{
Lailia Rahmawati $^{1}$,Achmad Maulana Hakimuddin ${ }^{2}$, Izzatul Umami ${ }^{3}$ \\ Jurusan Teknik Informatika, Fakultas Teknik, Universitas Darul 'Ulum Jombang 1 \\ Jurusan Teknik Informatika, Fakultas Teknik, Universitas Darul 'Ulum Jombang 2 \\ Jurusan Teknik Informatika, Fakultas Teknik, Universitas Darul 'Ulum Jombang 3 \\ liaundarjombang@gmail.com ${ }^{1}$, amhakim011@gmil.comi ${ }^{2}$, izzatul.umami@undar.ac.id ${ }^{3}$
}

\begin{abstract}
Abstrak - Daging sapi merupakan pangan penting dalam budaya dan tradisi makanan di Indonesia, walaupun konsumsi daging sapi relative lebih rendah dibandingkan dengan konsumsi ikan ataupun ayam broiler[5]. Bahan olahan makanan dari daging sapi haruslah dipilih yang berkualitas baik. Kualitas daging sapi bergantung dengan tingkat kesegaran daging sapi tersebut. Tingkat kesegaran daging sapi ditentukan dari warna, tekstur, rasa dan aroma. Penelitian ini merancang suatu sistem untuk menentukan tingkat kesegaran daging sapi dengan menggunakan neural network. Sistem ini memanfaatkan electronic nose dengan menggunakan sensor gas dengan jenis MQ-136 dan MQ-137. Data sensor diproses ke mikrokontroler dan mikrokontoler mengirimkan data sensor ke PC yang telah terprogram neural network. Hasil percobaan menunjukkan tingkat keberhasilan $70 \%$ dari 3 kali pengujian daging sapi segar dan tingkat keberhasilan terbaik $100 \%$ dari 3 kali pengujian daging busuk. Pada sistem ini diharapkan dapat menggantikan indra penciuman manusia dan membantu manusia untuk mendapatkan daging sapi yang segar dan layak konsumsi.
\end{abstract}

Kata kunci: daging sapi, kesegaran daging, sensor, electronic nose, neural network

\begin{abstract}
Beef is an important food in the culture and food tradition in Indonesia, although the consumption of beef is relatively lower than that of fish or broiler chickens [5]. Food processed ingredients from beef must be selected of good quality. The quality of beef depends on the freshness of the beef. The level of freshness of beef is determined by color, texture, taste and aroma. This study designed a system to determine the freshness of beef using a neural network. This system utilizes an electronic nose using gas sensors with the MQ-136 and MQ-137 types. Sensor data is processed to the microcontroller and the microcontroller sends sensor data to a PC that has been programmed with the neural network. The results of the experiment showed a success rate of $70 \%$ from 3 times of testing fresh beef and the best success rate of $100 \%$ from 3 times of rotten meat tests. In this system, it is hoped that it can replace the human sense of smell and help humans to get fresh beef and suitable for consumption.
\end{abstract}

Keywords: beef, freshness of meat, sensor, electronic nose, neural network

\section{PENDAHULUAN}

Daging sapi merupakan pangan penting dalam budaya dan tradisi makanan di Indonesia, walaupun 
konsumsi daging sapi relative lebih rendah dibandingkan dengan konsumsi ikan ataupun ayam broiler[5]. Untuk menjadi bahan olahan makanan daging sapi haruslah dipilih yang berkualitas baik. Kualitas daging sapi ini bergantung dengan tingkat kesegaran daging tersebut. Tingkat kesegaran daging sapi sendiri

ditentukan dari warna, tekstur, rasa dan aroma.

Dengan memanfaatkan aroma dari pembusukan daging sapi, digunakan sebuah electronic nose untuk dapat mendeteksi tingkat kesegaran daging sapi. Electronic nose sendiri terdiri dari dua buah sensor gas yang akan mendeteksi bau yang dikeluarkan oleh daging. Electronic nose atau penciuman elektronik adalah alat yang digunakan untuk menirukan prinsip kerja indra penciuman manusia. Elektronic nose terdiri dari rancangan elektronika sensor gas.

Penelitian terkait dengan penetuan tingkat kesegaran daging telah telah dilakukan dengan judul "Implementasi Sistem Penentuan Kesegaran Daging Sapi Lokal Berdasarkan Warna dan Kadar Amonia Dengan Metode Jaringan Saraf Tiruan Berbasis Embedded System". Proses penentuan kesegaran daging segar diperoleh berdasarkan nilai sensor warna TCS3200 dan sensor gas MQ-135. Selanjutnya meneruskan nilai pembacaan sensor dari Arduino menuju proses neural network.[1]

Pada penelitian ini digunakan sensor gas MQ-136 dan MQ-137. Kedua buah sensor MQ ini memiliki prinsip kerja dan karakteristik yang sama. Akan tetapi keduanya akan mendeteksi gas yang berbeda. Sensor MQ-136 dikhususkan untuk mendeteksi konsentrasi gas $\mathrm{H} 2 \mathrm{~S}$ atau hydrogen sulfida pada udara. Sedangkan untuk sensor MQ137 dikhususkan untuk mendeteksi keberadaan gas NH3 atau amonia di udara.[2]

Dari kedua sensor tersebut ada mikrokontroler yang bertugas sebagai pengatur dan pengolah data yang didapat pada kedua sensor tersebut. Mikrokontroler tersebut menggunakan Arduino Uno. Keunggulan dari mikokontroler ini yaitu open source, mudah dalam pengoperasiannya, ukuran kecil dan mudah di bawa, dan banyak referensi dari komunitas komunitas dari mikrokontroler tersebut.[3] Dalam penelitian ini mencoba meneliti kadar amonia dan hidrogen sulfida dengan menggunakan sensor gas MQ-136 dan MQ-137 sebagai idenfikasi daging sapi tersebut. Pada penelitian ini menganalisa daging sapi segar atau busuk dengan indikator yang didapat dari kedua sensor tersebut menggunakan metode neural network.

\section{Perancangan dan Implementasi}

\subsection{Blok Sistem}

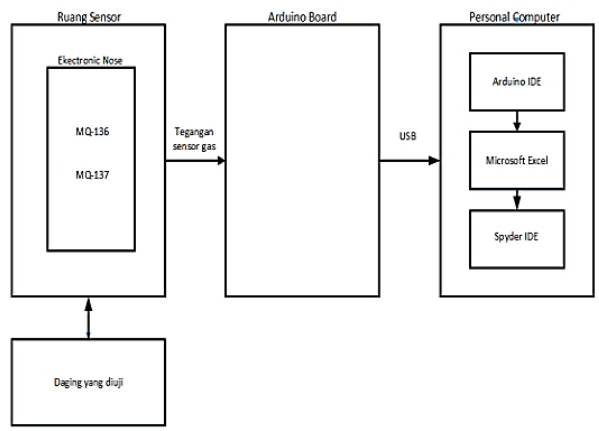

Gambar 1. Diagram Blok Pada Sistem

Pada gambar 1 Electronic nose terdiri atas array dari dua buah sensor gas yang berbeda yaitu MQ-136 dan MQ-137. Dua buah sensor gas tersebut akan dipaparkan terhadap aroma yang dikeluarkan oleh daging yang diuji. Sensor gas kemudian akan merespon aroma dari daging dengan menghasilkan nilai tegangan yang berbeda-beda bergantung terhadap tingkat kesegaran daging yang diuji. Nilai tegangan dari kedua buah sensor dalam electronic nose akan dibaca melalui mikrokontroller Arduino. Data berupa tegangan dari dua buah sensor selanjutnya akan disimpan dengan Microsoft Excel. Selanjutnya data akan diimport pada aplikasi pemrograman Spyder. Setelah data masuk maka data 
akan menuju proses pendeteksian dengan neural network.

\subsection{Perancangan Hardware}

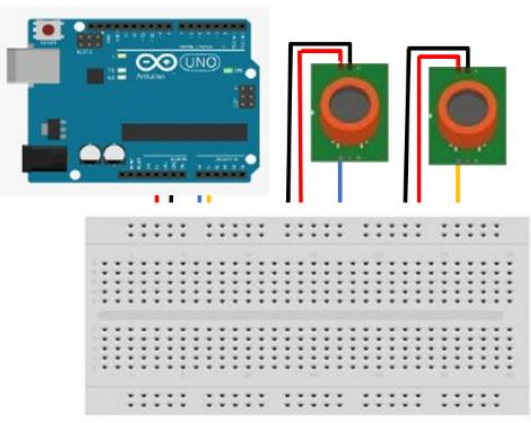

Gambar 2. Skema Electronic Nose

Pada gambar 2 dimana dua buah sensor gas dihubungkan dengan board Arduino. Kemudian dilanjutkan dengan pembangunan modul electronic nose berdasar skema yang telah dirancang. Dimana modul electronic nose dihubugkan dengan board Arduino dengan menggunakan kabel jumper. Keterangan gambar rangkaian electronic nose:

a) Kabel jumper hitam menghubungkan kaki GND dari setiap komponen ( MQ - 136 dan MQ - 137 ) ke pin GND (ground) pada Arduino Uno

b) Kabel jumper biru menghubungkan kaki AOUT MQ - 136 ke pin A0

c) Kabel jumper kuning menghubungkan kaki AOUT MQ - 137 ke pin A1

d) Kabel jumper merah menghbungkan kaki VCC dari setiap komponen ( MQ

136 dan MQ - 137 ) ke pin 5V

Setelah itu modul sensor dirangkai berdasarkan skema yang telah dirancang sebelumnya.

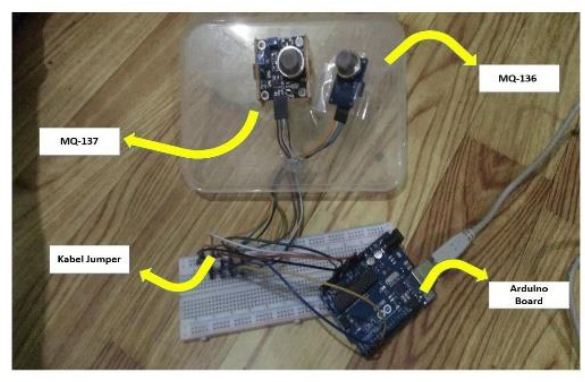

Gambar 3. Modul Electronic Nose

Setelahnya dibuatlah ruang sensor atau ruang uji untuk pendeteksian daging.

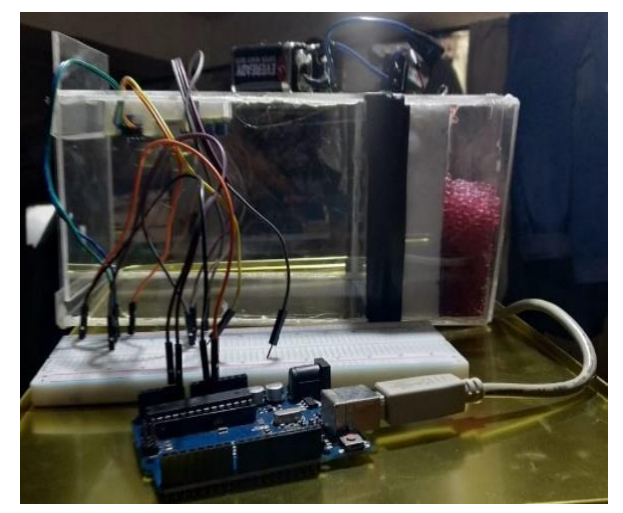

Gambar 4. Konstruksi Ruang Uji

Ruang uji ini berbentuk balok dengan bahan material pembuatannya adalah kaca acrilyc. Ditambahkan kipas sebagai alat bantu pembersihan udara pada ruang uji setelah digunakan. Juga ditambahkan silica gel untuk membantu kipas dalam menetralkan zat-zat kimia yang ada di udara, selain itu silica gel juga berfungsi untuk menekan pertumbuhan jamur pada ruang uji.

\subsection{Perancangan Software}

Perancangan electronic nose tidak hanya berfokus pada perancangan hardware saja. electronic nose yang dirancang juga akan dihubungkan dengan aplikasi 
Arduino untuk mengambil informasi berupa tegangan dari kedua buah sensor gas. Proses ini melibatkan pemrograman mikrokontroller pada Arduino. Hal yang pertama dilakukan adalah menginisialisasi variabel sensor gas. Maka digunakan sintaks pada Tabel 1.

Tabel 1 Source Code Inisialisasi Sensor

\begin{tabular}{|l}
\hline $1 \quad$ int rMQ_136 = analogRead $(\mathrm{AO}) ;$ \\
2 int rMQ_137 = analogRead $(\mathrm{Al}) ;$ \\
\hline
\end{tabular}

Karena nilai output dari sensor gas berupa nilai digital, maka harus diubah menjadi nilai analog. Untuk mengubahnya diperlukan nilai tegangan referensi yang umumnya bernilai sebesar 5 v. Selanjutnya digunakan sintaks pada Tabel 2.

Tabel 2 Source Code Konversi Nilai Sensor.

\begin{tabular}{|l|l|}
1 & float MQ_136 = rMQ_136 $*(5.00 / 1023.00) ;$ \\
2 & float MQ_137 = rMQ_137* $(5.00 / 1023.00) ;$ \\
\hline
\end{tabular}

Selanjutnya menampilkan nilai pembacaan dari sensor yang telah diubah ke niali analog. Sintaks pada Tabel 3.

Tabel 3 Source Code Konversi Nilai Sensor

\begin{tabular}{|ll|}
\hline 1 & Serial.print(MQ_136); \\
2 & Serial.print(MQ_137); \\
3 & Serial.println('\#); \\
\hline
\end{tabular}

Data yang diterima pada software Arduino akan ditampilkan dengan fitur serial monitor yang ada pada aplikasi Arduino. Data pada serial monitor selanjutnnya diterima oleh Microsoft Excel yang kemudian data tersebut disimpan dengan menggunakan format comma separated value (CSV).

Tahap senjutnya adalah perancangan neural network, arsitektur yang digunakan pada rancangan ini ditunjukkan pada gambar 5.

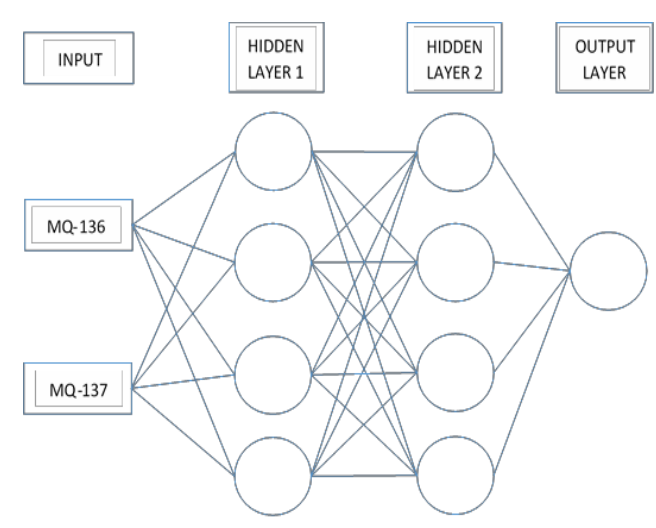

Gambar 5. Arsitektur Neural Network

Hal ini dibuat dengan aplikasi pemrograman Spyder.Spyder adalah aplikasi pemrograman berbasis ilmiah yang ditulis dalam bahasa pemrograman Python. Aplikasi ini banyak digunakan oleh para ilmuwan, insinyur, dan analis data.[4] Proses inisialisai neural network yang dilakukan dengan script pada Tabel 4.

Tabel 4 Source Code Inisialisasi Neural Network
1 int rMQ_136 = analogRead(A0);
2 int rMQ_137 = analogRead(A1);

Selanjutnya adalah mengimport data yang telah disimpan di folder komputer untuk ditampilkan ke Spyder. Setelah data berhasil diimport dilanjutkan dengan menjalankan program dengan menekan tombol run, saat berjalan proses training dan testing neural network akan dilakukan oleh program. Pada proses tersebut dikenal dengan istilah learning. Hasil dari learning ini disimpan sebagi model yang digunakan untuk proses deteksi kesegaran daging. 


\section{Pengujian dan Analisa}

\subsection{Pengujian Sensor MQ-136dan MQ-137}

Pengujian sensor gas dilakukan untuk mengetahui apakah sensor ini dapat mengambil data berupa nilai tegangan gas hidrogen sulfida dan ammonia pada objek daging dengan benar dan akurat.

Pada penelitian ini definisi mengenai tingkat kesegaran daging ditentukan melalui waktu penyimpanan daging di luar ruang ditunjukkan pada Tabel 5.

Tabel 5 Definisi Tingkat Kesegaran Daging yang Diuji

\begin{tabular}{|c|c|}
\hline $\begin{array}{c}\text { Tingkat } \\
\text { Kesegaran } \\
\text { Daging }\end{array}$ & Definisi Kesegaran Daging \\
\hline Segar & $\begin{array}{c}\text { Daging yang baru } \\
\text { disembelih/daging yang baru } \\
\text { keluar dari lemari pendingin }\end{array}$ \\
\hline Busuk & $\begin{array}{c}\text { Daging yang berada di luar } \\
\text { ruang selama satu hari atau lebih }\end{array}$ \\
\hline
\end{tabular}

Pengujian sensor gas yang pertama kali dilakukan adalah pengujian sensor gas saat tidak terdapat sampel daging pada ruang uji sensor atau dengan kata lain ruang sensor berisi udara bersih yang ditunjukkan pada tabel 6 .
Tabel 6 Nilai Sensor Terhadap Udara Bersih

\begin{tabular}{|c|c|c|}
\hline Input & MQ136 & MQ137 \\
\hline 1 & 0.99 & 0.82 \\
\hline 2 & 0.99 & 0.82 \\
\hline 3 & 0.98 & 0.82 \\
\hline 4 & 0.98 & 0.82 \\
\hline 5 & 0.98 & 0.82 \\
\hline 6 & 0.97 & 0.82 \\
\hline 7 & 0.96 & 0.82 \\
\hline 8 & 0.96 & 0.82 \\
\hline 9 & 0.96 & 0.82 \\
\hline 10 & 0.96 & 0.82 \\
\hline
\end{tabular}

Berdasarkan nilai pada tabel terlihat bahwa nilai respon sensor terhadap udara bersih. Grafik nilai sensor terhadap udara bersih akan disajikan pada gambar 6 .

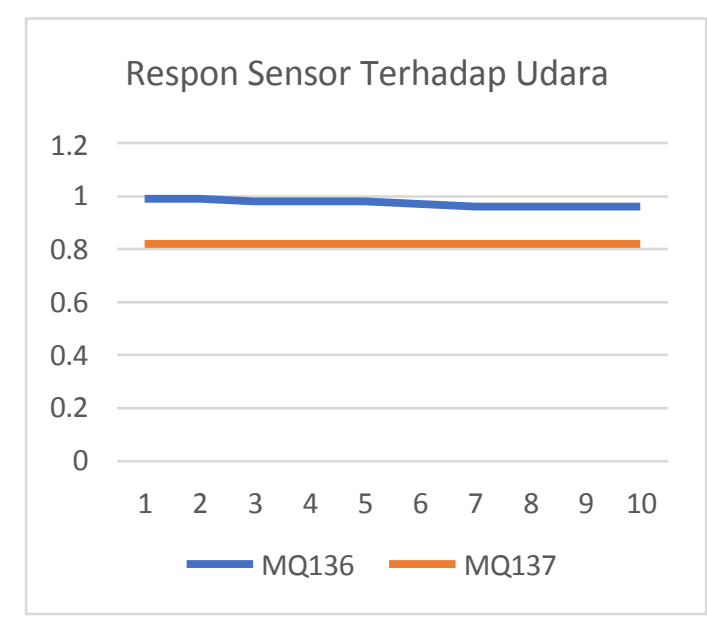

Gambar 6. Grafik Sensor Terhadap Udara Bersih

Terlihat pada grafik kedua sensor tidak mengalami perubahan niali yang signifikan. Selanjutnya pengujian sensor gas terhadap sampel daging dimulai dengan sampel berupa daging segar yang ditunjukkan pada tabel 7 . 
Tabel 7 Nilai Sensor Terhadap sampel daging

\begin{tabular}{|c|c|c|c|}
\hline Input & MQ136 & MQ137 & Status \\
\hline 1 & 0.99 & 0.87 & Segar \\
\hline 2 & 0.99 & 0.86 & Segar \\
\hline 3 & 0.99 & 0.88 & Segar \\
\hline 4 & 0.99 & 0.89 & Segar \\
\hline 5 & 0.99 & 0.85 & Segar \\
\hline 6 & 0.99 & 0.87 & Segar \\
\hline 7 & 1 & 0.86 & Segar \\
\hline 8 & 0.99 & 0.87 & Segar \\
\hline 9 & 1 & 0.85 & Segar \\
\hline 10 & 1 & 0.85 & Segar \\
\hline
\end{tabular}

Berdasarkan nilai pada tabel terlihat bahwa nilai respon sensor terhadap daging segar.

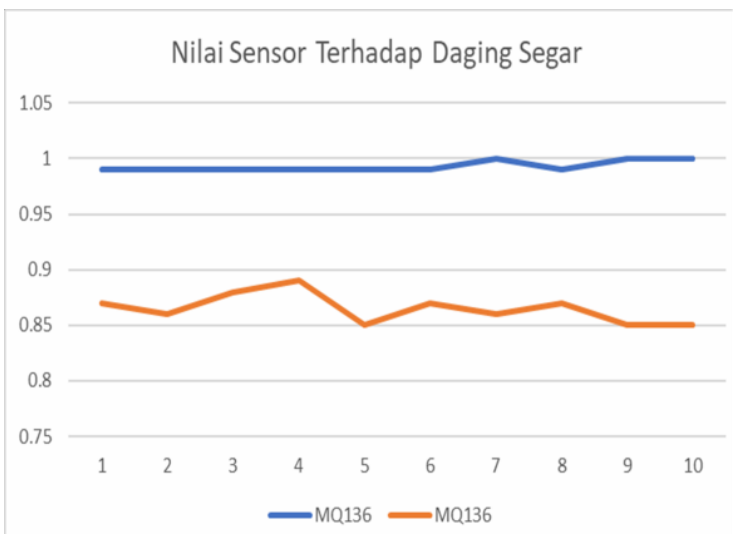

Gambar 7. Grafik Nilai Sensor Terhadap Daging Segar

Pada grafik di atas terlihat mulai ada perubahan pola pada nilai sensor.

Selanjutnya adalah pengujian terhadap daging busuk, pada tahap ini daging memiliki bau yang menyengat. Ditunjukkan pada Tabel 8.
Tabel 8 Nilai Sensor Terhadap Daging Busuk

\begin{tabular}{|c|c|c|c|}
\hline Input & MQ136 & MQ137 & Status \\
\hline 1 & 1.28 & 2.04 & Busuk \\
\hline 2 & 1.37 & 2.17 & Busuk \\
\hline 3 & 1.35 & 2.36 & Busuk \\
\hline 4 & 1.37 & 2.6 & Busuk \\
\hline 5 & 1.39 & 2.8 & Busuk \\
\hline 6 & 1.42 & 2.97 & Busuk \\
\hline 7 & 1.46 & 3.12 & Busuk \\
\hline 8 & 1.51 & 3.24 & Busuk \\
\hline 9 & 1.56 & 3.33 & Busuk \\
\hline 10 & 1.61 & 3.41 & Busuk \\
\hline
\end{tabular}

Berdasarkan nilai pada tabel terlihat bahwa nilai respon sensor terhadap daging busuk.

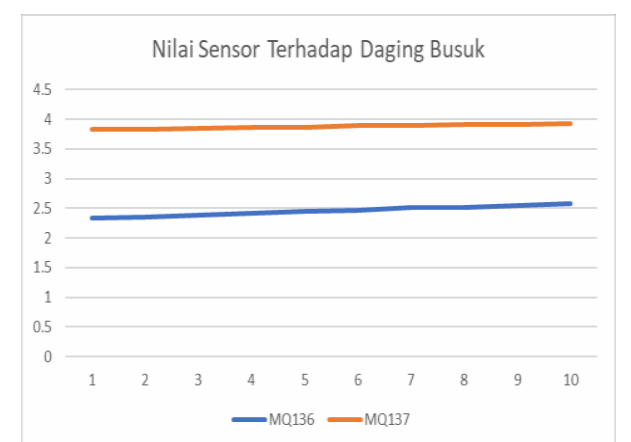

Gambar 8. Grafik Nilai Sensor Terhadap Daging Busuk

Grafik tersebut menunjukkan pola pada nilai tegangan sensor yang naik. Hal ini menjadi representasi keadaan daging sapi yang sudah mengalami pembusukan.

Hasil pengujian sensor gas pada sampel daging segar dan daging busuk, terdapat kenaikan nilai tegangan pada kedua buah sensor. Apabila dibandingkan, hasil pengujian sensor terhadap daging busuk memiliki kenaikan yang lebih tinggi daripada hasil pengujian sensor terhadap daging segar. Hal ini mengindikasikan jika kedua buah sensor tersebut merespon terhadap aroma yang dihasilkan 
oleh daging selama proses pengujian daging.

\subsection{Pengujian Program Neural Network}

Langkah awal yang dilakukan adalah mengumpulkan 60 data dari dua kondisi daging yang berbeda. Daging yang digunakan sebagai sampel ini merupakan daging sapi berukuran 2 ons. Pada daging segar dikumpulkan 30 data dan pada daging busuk dikumpulkan 30 data. Setelah data didapat kemudian digabungkan dalam satu dataset pada Tabel 9.

Tabel 9 Dataset (ditampilkan 10 dari 60 buah data)

\begin{tabular}{|c|c|c|c|}
\hline Input & MQ136 & MQ137 & Status \\
\hline 1 & 0.99 & 0.85 & Segar \\
\hline 2 & 2.12 & 3.9 & Busuk \\
\hline 3 & 0.96 & 0.82 & Segar \\
\hline 4 & 1.46 & 3.12 & Busuk \\
\hline 5 & 1 & 0.85 & Segar \\
\hline 6 & 2.25 & 3.95 & Busuk \\
\hline 7 & 0.96 & 0.82 & Segar \\
\hline 8 & 1 & 0.83 & Segar \\
\hline 9 & 1.83 & 3.69 & Busuk \\
\hline 10 & 1.35 & 2.36 & Busuk \\
\hline & & & \\
\hline
\end{tabular}

Selanjutnya melakukan running program.

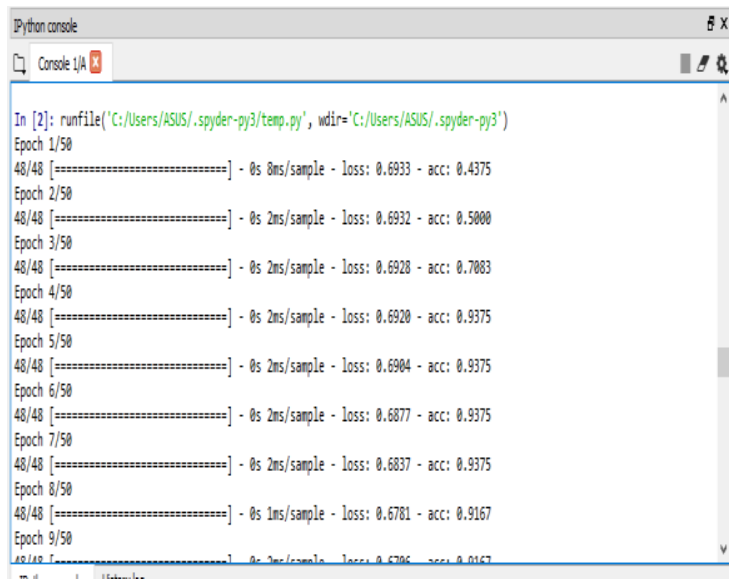

Gambar 10. Proses Pembelajaran

Pada proses tersebut dataset akan dibagi menjadi dua yaitu data train dan data test. Data train terdiri dari 38 buah data dan data test terdiri dari 12 buah data. Setelah proses pembelajaran selesai program akan menunjukkan hasil.

Hasil proses learning ini akan menghasilkan keluaran true dan false, dengan true mendifinisikan daging busuk sedangkan false mendifinisikan daging segar. Hasil ditampilkan pada gambar.

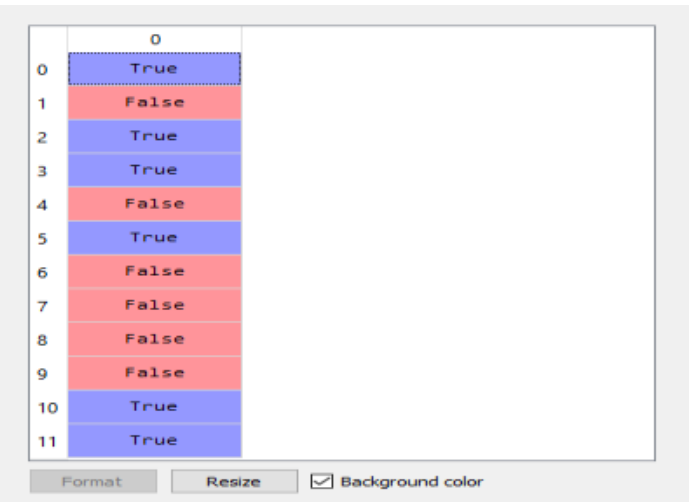

Gambar 12. Hasil Pembelajaran

Dari 12 data test tersebut menghasilkan keluaran 6 nilai true dan 6 nilai false yang berarti 6 keluaran daging busuk dan 6 keluaran daging segar. Proses pembelajaran/learning ini kemudian disimpan sebagai model. 
VOL. 11 No. 2 BULAN APRIL 2021

\subsection{Pengujian Model}

Pada pengujian model ini dilakukan menggunakan tiga data test yang diperoleh dari sampel daging segar dan tiga data test yang diperoleh dari sampel daging busuk masingmasing berisi 10 buah data. Sampel yang digunakan merupakan daging dengan berat sebesar 2 ons. Pengujian dilakukan sebagaimana berikut :

\section{a) Data test daging segar yang pertama}

Tabel 10 Hasil Pengujian Data Test Daging Segar Pertama

\begin{tabular}{|c|c|c|c|c|c|}
\hline Input & MQ136 & MQ137 & Identifikasi & Hasil & Keterangan \\
\hline 1 & 0.99 & 0.87 & FALSE & Segar & Benar \\
\hline 2 & 0.99 & 0.86 & TRUE & Busuk & Salah \\
\hline 3 & 0.99 & 0.88 & FALSE & Segar & Benar \\
\hline 4 & 0.99 & 0.89 & FALSE & Segar & Benar \\
\hline 5 & 0.99 & 0.85 & TRUE & Busuk & Salah \\
\hline 6 & 0.99 & 0.87 & FALSE & Segar & Benar \\
\hline 7 & 1 & 0.86 & FALSE & Segar & Benar \\
\hline 8 & 0.99 & 0.87 & FALSE & Segar & Benar \\
\hline 9 & 1 & 0.85 & TRUE & Busuk & Salah \\
\hline 10 & 1 & 0.85 & TRUE & Busuk & Salah \\
\hline
\end{tabular}

Dari tabel di atas dapat diketahui bahwa dari 10 data test daging segar menghasilkan 6 input diidentifikasi sebagai daging segar dan 4 input sebagai daging busuk. Dengan demikian pada percobaan pertama ini mencapai $60 \%$ keberhasilan.

\section{b) Data test daging segar yang kedua}

Tabel 11 Hasil Pengujian Data Test Daging Segar Kedua

\begin{tabular}{|c|c|c|c|c|c|}
\hline Input & MQ136 & MQ137 & Identifikasi & Hasil & Keterangan \\
\hline 1 & 0.98 & 0.86 & TRUE & Busuk & Salah \\
\hline 2 & 0.98 & 0.86 & TRUE & Busuk & Salah \\
\hline 3 & 0.98 & 0.88 & FALSE & Segar & Benar \\
\hline 4 & 0.99 & 0.87 & FALSE & Segar & Benar \\
\hline 5 & 0.99 & 0.86 & TRUE & Busuk & Salah \\
\hline 6 & 0.99 & 0.87 & FALSE & Segar & Benar \\
\hline 7 & 1 & 0.88 & FALSE & Segar & Benar \\
\hline 8 & 0.99 & 0.87 & FALSE & Segar & Benar \\
\hline 9 & 1 & 0.88 & FALSE & Segar & Benar \\
\hline 10 & 0.99 & 0.88 & FALSE & Segar & Benar \\
\hline
\end{tabular}

Dari tabel di atas dapat diketahui bahwa dari 10 data test daging segar menghasilkan 7 input diidentifikasi sebagai daging segar dan 3 input sebagai daging busuk. Dengan demikian pada percobaan kedua ini mencapai $70 \%$ keberhasilan.

\section{c) Data test daging segar yang ketiga}

Tabel 12 Hasil Pengujian Data Test Daging Segar Ketiga

\begin{tabular}{|c|c|c|c|c|c|}
\hline Input & MQ136 & MQ137 & Identifikasi & Hasil & Keterangan \\
\hline 1 & 0.98 & 0.86 & TRUE & Busuk & Salah \\
\hline 2 & 0.98 & 0.86 & TRUE & Busuk & Salah \\
\hline 3 & 0.98 & 0.88 & FALSE & Segar & Benar \\
\hline 4 & 0.99 & 0.87 & FALSE & Segar & Benar \\
\hline 5 & 0.99 & 0.86 & TRUE & Busuk & Salah \\
\hline 6 & 0.99 & 0.87 & FALSE & Segar & Benar \\
\hline 7 & 1 & 0.88 & FALSE & Segar & Benar \\
\hline 8 & 0.99 & 0.87 & FALSE & Segar & Benar \\
\hline 9 & 1 & 0.88 & FALSE & Segar & Benar \\
\hline 10 & 0.99 & 0.88 & FALSE & Segar & Benar \\
\hline
\end{tabular}

Dari tabel di atas dapat diketahui bahwa dari 10 data test daging segar menghasilkan 7 input diidentifikasi sebagai daging segar dan 3 input sebagai daging busuk. Dengan demikian pada percobaan kedua ini mencapai $70 \%$ keberhasilan. 


\section{d) Data test daging busuk yang pertama}

Tabel 13 Hasil Pengujian Data Test Daging Busuk Pertama

\begin{tabular}{|c|c|c|c|c|c|}
\hline Input & MQ136 & MQ137 & Identifikasi & Hasil & Keterangan \\
\hline 1 & 2.33 & 3.83 & TRUE & Busuk & Benar \\
\hline 2 & 2.35 & 3.83 & TRUE & Busuk & Benar \\
\hline 3 & 2.38 & 3.85 & TRUE & Busuk & Benar \\
\hline 4 & 2.41 & 3.87 & TRUE & Busuk & Benar \\
\hline 5 & 2.44 & 3.87 & TRUE & Busuk & Benar \\
\hline 6 & 2.47 & 3.89 & FALSE & Segar & Salah \\
\hline 7 & 2.52 & 3.9 & FALSE & Segar & Salah \\
\hline 8 & 2.52 & 3.91 & FALSE & Segar & Salah \\
\hline 9 & 2.55 & 3.91 & FALSE & Segar & Salah \\
\hline 10 & 2.57 & 3.92 & FALSE & Segar & Salah \\
\hline
\end{tabular}

Dari tabel di atas dapat diketahui bahwa dari 10 data test daging busuk menghasilkan 5 input diidentifikasi sebagai daging busuk dan 5 input sebagai daging segar. Dengan demikian pada percobaan ini mencapai $50 \%$ keberhasilan.

\section{e) Data test daging busuk yang kedua}

Tabel 14 Hasil Pengujian Data Test Daging Busuk Kedua

\begin{tabular}{|c|c|c|c|c|c|}
\hline Input & MQ136 & MQ137 & Identifikasi & Hasil & Keterangan \\
\hline 1 & 2.02 & 3.69 & TRUE & Busuk & Benar \\
\hline 2 & 2.07 & 3.71 & TRUE & Busuk & Benar \\
\hline 3 & 2.11 & 3.73 & TRUE & Busuk & Benar \\
\hline 4 & 2.15 & 3.75 & TRUE & Busuk & Benar \\
\hline 5 & 2.19 & 3.77 & TRUE & Busuk & Benar \\
\hline 6 & 2.23 & 3.78 & TRUE & Busuk & Benar \\
\hline 7 & 2.27 & 3.8 & TRUE & Busuk & Benar \\
\hline 8 & 2.31 & 3.82 & TRUE & Busuk & Benar \\
\hline 9 & 2.35 & 3.83 & TRUE & Busuk & Benar \\
\hline 10 & 2.38 & 3.85 & TRUE & Busuk & Benar \\
\hline
\end{tabular}

Dari tabel di atas dapat diketahui bahwa dari 10 data test daging busuk menghasilkan 10 input diidentifikasi sebagai daging busuk dan tidak ada input sebagai daging segar. Dengan demikian pada percobaan ini mencapai $100 \%$ keberhasilan.

\section{f) Data test daging busuk yang ketiga}

Tabel 15 Hasil Pengujian Data Test Daging Segar Ketiga

\begin{tabular}{|c|c|c|c|c|c|}
\hline Input & MQ136 & MQ137 & Identifikasi & Hasil & Keterangan \\
\hline 1 & 2.31 & 3.82 & TRUE & Busuk & Benar \\
\hline 2 & 2.35 & 3.83 & TRUE & Busuk & Benar \\
\hline 3 & 2.38 & 3.85 & TRUE & Busuk & Benar \\
\hline 4 & 2.41 & 3.86 & TRUE & Busuk & Benar \\
\hline 5 & 2.44 & 3.87 & TRUE & Busuk & Benar \\
\hline 6 & 2.47 & 3.89 & FALSE & Segar & Salah \\
\hline 7 & 2.5 & 3.9 & FALSE & Segar & Salah \\
\hline 8 & 2.52 & 3.91 & FALSE & Segar & Salah \\
\hline 9 & 2.55 & 3.91 & FALSE & Segar & Salah \\
\hline 10 & 2.57 & 3.92 & FALSE & Segar & Salah \\
\hline
\end{tabular}

Dari tabel di atas dapat diketahui bahwa dari 10 data test daging busuk menghasilkan 5 input data diidentifikasi sebagai daging busuk dan 50 input data sebagai daging segar. Dengan demikian pada percobaan ini mencapai $50 \%$ keberhasilan.

\section{Kesimpulan}

Berdasarkan hasil pengujian dan analisa dari sistem yang telah dibuat dapat ditarik beberapa buah kesimpulan. Pada pengujian sensor gas MQ-136 dan MQ-137 didapatkan pola tegangan yang berbeda terhadap 2 buah sampel daging dengan tingkat kesegaran yang berbeda. Melalui penggunaan metode neural network, sistem yang dibangun dapat melakukan pengenalan pola terhadap tingkat kesegaran daging dengan tingkat keberhasilan mencapai 50\%. Pada 3 
kali pengujian model terhadap daging segar didapat hasil terbaik mencapai angka keberhasilan 70\%. Sedangkan pada 3 kali pengujian model terhadap daging busuk didapat hasil terbaik mencapai angka keberhasilan $100 \%$.

Hasil pengujian pada daging segar dan daging busuk mengalami pembacaan nilai yang berubah-ubah. Hal ini dipengaruhi oleh beberapa faktor diantaranya:

1) Kondisi sampel daging sapi yang diujikan telah berada diluar ruang selama proses pengujian. Hal ini mengakibatkan sampel daging terkontaminasi oleh kondisi udara di luar ruang.

2) Kondisi ruang uji electronic nose belum bersih saat digunakan. Aroma pada sampel daging yang telah diujikan masih menempel pada ruang uji electronic nose meskipun telah dibersihkan dengan bantuan kipas dan silica gel.

3) Kabel jumper tidak terpasang dengan sempurna pada breadboard sehingga mempengaruhi proses pengambilan data.

4) Model neural network tidak di train ulang sebelum diujikan. Hal ini membuat model kurang mengenali pola terhadap data-data baru yang diujikan.

5) Jumlah dataset teralu sedikit untuk perancangan model neural network.

Beberapa saran yang penulis bisa berikan untuk pengembangan penelitian ini di masa yang akan datang adalah keakuratan pengujian pada tingkat kesegaran daging dapat ditambahkan jenis sensor gas lain dan ditingkatkan dengan menambahkan jumlah data training dari neural network. Selain itu proses identifikasi tingkat kesegaran daging dapat menggunakan metode kecerdasan lain seperti recurrent neural network, PCA, dan rekayasa genetika.

\section{REFERENSI}

[1] Haman Bagus Firmansyah, Dahniel SauqY, Mohammad Hannats Hanafi Ichsan, "Implementasi Sistem Penentuan Kesegaran Daging Sapi Lokal Beradasarkan Warna dan Kadar Amonia engan metode Jaringan syaraf tiruan berbasis Embedde system", Jurnal Pengembangan Teknologi Informasi dan Ilmu Komputer, Vol. 3, No.5. 2019.

[2] Abdul Kadir, From Zero To A Pro Arduino. Yogyakarta, Andi, 2015

[3] “Arduino Playground, https://playground.arduino.cc/, diakses pada 20 Mei 2019

[4] "Overview”, https://www.spyder-ide.org/, diakses pada 17 Mei 2019

[5] Marc L'Huillier, David Primrose, Hannah Stewart danJillian Harriot.

Tren konsumsi dan preferensi daging sapi di IndonesiaAustralia. 2018

[6] Soeparno.Ilmu dan Teknologi Daging. Gadjah Mada University Press. Yogyakarta. 1992.

[7] Astawan, P. D. (2004, Mei). Pentingnya mengkonsumsi daging. http://peternakantaurus.wordpress.com/2010/07/26/penting nyamengkonsumsi-daging diakses 17 Mei 2019

[8] Adam, Agus Setiawan, Marzuwarman, "Implementasi Neural network untuk Menentukan Kesegaran Daging Ikan Tongkol” Jurnal Inovtek Polbeng, Vol. 09, No.1, 2019.

[9] Nadya, Ayu dan Nafiasari, "Penganalisisan Kesegaran Daging Sapi Dan Daging Babi Berdasarkan Klasifikasi Warna Dan Kelembaban", 2018.

[10] Standar Nasional Indonesia. Mutu Karkas Dan Daging Sapi. Jakarta. Badan Standarisasi Nasional 10687 SNI 3932 -2008

[11] Muhammad Rivai, Fajar Budiman, Djoko Purwanto And 4joshwa Simamora, Meat Freshness Identification System Using Gas Sensor Array And Color Sensor In Conjunction With Neural Network Pattern Recognition, Journal of Theoretical and Applied Information Technology . Vol.96. No 12. 2018

[12]Purnama. Benny, Pengantar Machine Learing, Bandung, Informatika, 2019. 
[13]E. Risdianto dan M. Wiwit, 43 Trik Cepat Belajar Excel, Jakarta, Halaman Moeka Publishing, 2019. 